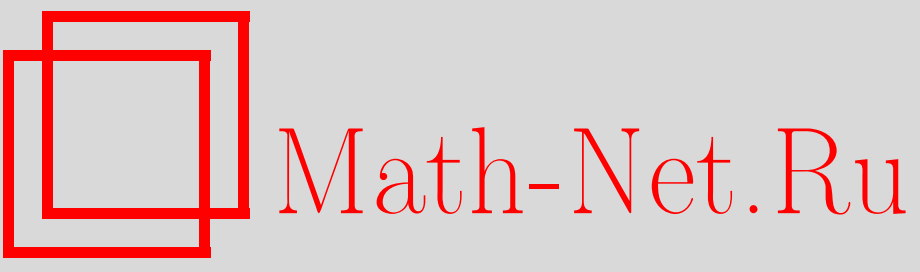

Конкурс Мёбиуса, УМН, 2005, том 60, выпуск 3, 189-190

DOI: https://doi.org/10.4213/rm1441

Использование Общероссийского математического портала Math-Net.Ru подразумевает, что вы прочитали и согласны с пользовательским соглашением

http://www.mathnet.ru/rus/agreement

Параметры загрузки:

IP : 54.80 .73 .141

26 апреля 2023 г., 13:15:27 


\section{КОНКУРС МЁБИУСА}

\section{Положение о конкурсе Мёбиуса}

Цели. Конкурс Августа Мёбиуса учрежден для выявления лучших студенческих и аспирантских научных работ по математике и для оказания финансовой поддержки их авторам.

Участники. В конкурсе могут участвовать очные студенты и аспиранты любых российских вузов (а также очные аспиранты научно-исследовательских институтов), имеющие этот статус на 1 июня года проведения конкурса. Не имеют права участвовать в конкурсе победители (первая, вторая и третья премия) конкурса предыдущего года.

Оформление работы. Участник должен представить на конкурс одну самостоятельную научную работу по математике (или по математической физике, но написанную на математическом уровне строгости) по адресу: Москва, 119002, Б. Власьевский пер. 11, Конкурс Мёбиуса.

Работа должна быть прислана в двух экземплярах (весьма желательно приложить и электронную версию на дискете). K работе необходимо приложить следующие сведения:

- фамилия, имя и отчество участника конкурса;

- фамилия, имя и отчество научного руководителя;

- наименование учебного заведения, курс (для студентов) или год обучения (для аспирантов);

- почтовый адрес (с индексом);

- электронный адрес;

- контактный телефон.

Участник может (но не обязан) приложить отзыв научного руководителя на свою работу.

Подача работ по электронной почте. При невозможности послать работу по почте или доставить в НМУ лично, можно отослать работу в электронном виде (postscript- и $\mathrm{TE}_{\mathrm{E}} \mathrm{X}$-файлы плюс анкета) по адресу: moebius@mccme.ru.

Соавторство. Работы в соавторстве допускаются, только если они сопровождаются письмом соавторов, указывающих, какие именно части работы выполнены конкурсантом самостоятельно.

Сроки. Конкурс состоит из двух туров и проводится в ноябре-декабре. Крайний срок подачи работ - 15 октября.

Жюри. Для проведения конкурса учреждено жюри конкурса Мёбиуса, которое состоит из председателя, ученого секретаря, двух учредителей конкурса и ряда специалистов. Состав жюри может быть расширен в резултате единогласного решения его членов (при наличии кворума). Кворум устанавливается как треть состава жюри.

Рецензирование. Жюри посылает работы, представленные на конкурс, на рецензию экспертам. 
Освещение хода и результатов конкурса. Списки работ, поданных на конкурс, а также вьшедших в финал, публикуются на web-странице конкурса. Кроме того, публикуются полные тексты работ, вышедших в финал (при отсутствии запрета на такую публикацию от автора).

Секретарь. Для выполнения технической работы, связанной с конкурсом, назначается секретарь, который выполняет эту работу согласно должностной инструкции за соответствующее вознаграждение.

Первый тур. По истечении срока подачи работ жюри отбирает среди присланных работ те, что допускаются к участию в конкурсе, и отправляет их на рецензии соответствующим специалистам (как членам жюри, так и на внешний отзыв). Среди отобранных работ, руководствуясь отзьвами и собственным мнением, жюри выбирает 6-7 лучших для участия в финальном, устном туре. По возможности, это решение достигается консенсусом, иначе председатель жюри назначает рейтинговое голосование.

Финальный тур. Финальньй устный тур проводится в конференц-зале НМУ (Б. Власьевский, 11, 4 этаж) в декабре. Он открыт для всех желающих. На него приглашаются участники, отобранные жюри в резултате первого тура. (При необходимости, иногородним финалистам оплачивается дорога в Москву и обратно.)

Участники финалшного тура выступают с кратким сообщением о своей работе и отвечают на вопросы жюри. После этого жюри на закрытом заседании отбирает первого, второго и третьего призера конкурса. (В исключительных случаях жюри может не присудить одну из премий или присудить две первые или две вторые премии.) По возможности, решение жюри достигается консенсусом, иначе председатель жюри назначает рейтинговое голосование.

Награды. Победители конкурса награждаются грамотами Независимого московского университета и двухлетними стипендиями в размере (рублевого эквивалента) $\$ 300, \$ 250, \$ 200$ за первое, второе и третье место соответственно. Стипендии выплачиваются ежемесячно в течение двух лет, начиная с января, кроме тех месящев, в течение которых стипендиат находится за границей болшшую часть месяца.

\section{Состав жюри}

В жюри конкурса входят В.У. Баликоев, В. К. Белошапка, Ю. М. Бурман, В. А. Василев, Э. Б. Винберг, А. Л. Городенцев, С. М. Гусейн-Заде, Pierre Deligne, Ю. С. Ильяшенко, В. Ю. Калошин, А. А. Кокин, С. К. Ландо, С.М. Натанзон, А. Г. Сергеев, А.Б. Сосинский (секретарь), Б. Л. Фейгин (председатель), М. А. Цфасман, А. Шень. 